\title{
The Application of Activity-based Method in English Reading Teaching in Senior High School
}

\author{
Xuejuan Duan \\ China West Normal University, Nanchong, Sichuan, China
}

\begin{abstract}
Activity-based method in English reading teaching in senior high school is put forward in the new National English Curriculum Standards for Senior High School (NECS). With the development of the times, the demand for hundreds of thousands of senior high school English teachers is changing, because educators stress a great attention to the application of the modern information technology and activity-based method. Therefore, around how to apply English activity-based method in the reading teaching in high school, this paper designs three learning activities to address the problems of the traditional teacher-centered teaching and the knowledge-orientated leaning. The result of this study can penetrate the consciousness of practical meaning into the frontline teachers by fully understanding the new conception and implementing it based on their own teaching needs.
\end{abstract}

Key words: activity-based method; senior high school English; reading teaching

\section{Introduction}

During course of teaching English, instructors know that reading teaching takes place in cultivating students' key competence. They spare no expense to let student to get the highest scores in each test, regardless of comprehensive development of student' thinking quality and culture awareness. But with the publication of NECS, teachers are supposed to update their model of teaching in senior high school. There is an evidence that the teacher is the most important factor influencing students' learning (Scarino, 2013). As a result, the activity encourages English teachers to integrate teaching content, recombine teaching factors, motivate students at learning, and conduct teaching in depth.

This paper is a study to implement activity-based method, and it takes a text from senior English book published by Foreign Language Teaching and Research Press (Miao, 2011). The text is taken from Unit 5, "Great People and Great Inventions of Ancient China: Philosophers of Ancient China" (Li, 2019). The new NECS requires that English learning activities should be comprehensive, relevant, and practical, and the design should promote the student's key competences (NECS, 2018). English reading competence not only includes students' learn ability, but also the ability to internalize and use the acquired language knowledge to build meaning (Wang, 2017). Therefore, starting from the above problems, this paper focuses on how to help teachers be aware of the necessity of activity-based method in English reading teaching and how to implement it in reading teaching in senior high school. During the same period, teachers should continuously summarize practical experience to change the current situation.

\section{The Connotation of Activity-based Method in English}

Scrivener provides definition of activity, that is, "something that learners do that involves them using or working with

Copyright (C) 2021 by author(s) and Frontier Scientific Research Publishing Inc.

This work is licensed under the Creative Commons Attribution International License (CC BY 4.0).

$\mathrm{http} / / /$ creativecommons.org/licenses/by/4.0/ 
language to achieve some specific outcome." The outcome may help students communicate with people around them, or it is unalloyed "for-the-purpose-of-learning" outcome. The aim of learning activities is to increase the key competence of this discipline (Li Yang, 2014). Accordingly, English teaching can show clearly the student-centered teaching concept, and design all kinds of meaningful activities for teaching.

\section{The Design of English Reading Teaching Activities}

Reading plays a significant role in English teaching. Teachers should explore the meaning of the theme as the main line of teaching activities. Therefore, this paper takes the concept of implementing English learning activities as the basis. In teaching activities, various teaching activities are guided step by step to help students achieve a deep understanding of the meaning of the topic.

\subsection{Learning and comprehending activities}

This kind of activities refers to discoursed-based learning activities. Learning comprehension is the first stage of the concept of English learning activities (NECS, 2018, 62-63). And activating students' existing knowledge and stimulating interest in English learning is conducive to an incisive understanding of the text.

Activity 1: Make full use of modern multimedia technology to create teaching situations and stimulate students' existing knowledge. In this class, the teacher will play a short video about the allusions during the Spring and Autumn Period and the Warring States Period to let students think about the name of the allusion and explain the ins and outs of the story.

Design description: NECS requires the ability to listen, speak, write, read, as well as watch should not be neglected. This paper creates a situation through a multimedia and vividly shows the story of three times of Mencius mother's move.

Activity 2: Teachers guide students to pay attention to the title and three portraits of this text. Firstly, students have a minute to think independently. Secondly, students screw up their courage to actively participate in this activity via answering questions showed on the power point. Then teachers guide students to predict the main meaning of this text.

Q1: What the tittle of this passage?

Q2: Can you recognize the three portraits? And can you guess who are they?

Suggested answers: Philosophers of Ancient China; Confucius, Mencius, Mozi

Design description: Questions are put forward before reading to encourage students to read with a purpose. And the teacher helps students predict the meaning of the text from the tittle and pictures. Nuttall points out five types of questions: Questions about the literal meaning of the text, questions of comprehensively generalizing the text, questions of guiding reasoning, questions of guiding the evaluation of the text, and questions of guiding students to express their personal opinions on the text (Nuttall, 2000).

\subsection{Application practice activities}

This kind of activities refers to learning activities that go deep into the discourse, including cognitive activities such as description and interpretation, analysis and judgement, internalization and application (NECS, 2018).

Activity 3: There are some phrases that students can recognize and understand.

Design description: Teachers should help students achieve goals in vocabulary learning with productive and receptive words. Furthermore, students are supposed to infer meanings of vocabulary either from context or though the existing formation. However, it is impossible that students can remember all words, so their vocabulary stock should expand gradually.

Activity 4: Use the transition device in the reading strategy to integrate the information in the text. The teacher asks the classmates to quickly scan the text and then complete a table. Take Table 1 as an Example. 
Table 1. The basic information

\begin{tabular}{llllll}
\hline Name & Year of Birth & Length of Living & Background & Ideas & Influence \\
\hline Confucius & & & \\
Mencius & & \\
Mozi & & \\
\hline
\end{tabular}

Design description: It is important that students fill out the table while reading instead of after reading. Through the transition device, English reading converts content of the text into a clearly structured table. Students are engaged in reading quickly and actively in order to complete the table and fully exercise their ability to use scanning skills in reading.

Activity 5: Answer questions

The teacher divides the whole class into six groups for class competitions and carries on task-based reading. It is best for the teacher to wait for $70 \%$ of the students in the class who have completed the task. Each time anyone of the students in one group raise their hands and answer a question correctly, the group scores one point (a total of 5 points), which also realizes the classroom teaching of group competition.

Q1: Whose impact has been greatest?

Q2: Why Mencius resigned from his job in the government?

Q3: Why Mencius considered that man is different from animal?

Q4: How Mozi became well-know when he was very poor?

Q5: What is the relationship among Confucius, Mencius and Mozi?

Suggested answers: Q1: Confucius; Q2: Because the government didn't fallow the rule he made; Q3: Man is good; Q4: Because of his unusual clothes and behavior; Q5: Mencius is Confucius'student and Mozi’s belief is similar to Confucius.

Design description: Vygotsky's most famous contribution is Zone of Proximal Development (ZPD) and scaffolding, that is to say, learning process is an interaction between teachers, peers and others. As a result, the sociocultural perspective on second language learning emphasizes that all learning including language is on the ground of social interaction with more prominent others. Teachers work with these perceptions in order to facilitate learning English.

Activity 6: Show these short sentences on the screen first, let students translate, and then invite some volunteers to tell who said these typical sentences after getting familiar with the text.

(1) Everyone is equal.

(2) Human nature is good.

(3) Do not unto others do what you would not have them do unto you.

(4) We should love all the human beings.

(5) People is more important than rulers.

Suggested answer: "(1)" is said by Mozi; “(2)" is said by Mencius; "(3)" is said by Confucius; "(4)" is said by Mozi; “(5)" is said by Mencius.

Design description: Let students translate those sentences will exercise their ability of translation. Besides, they can understand the text deeper than before by reading the text again. Schema theory has an important guiding significance for English reading teaching. Foreign scholars believe that the degree of texts understanding in the process of reading depends on their background knowledge and newly-acquired knowledge (Ren, 2019). And active establishment of diagrams learners can promote active thinking (Sun, 2007,188-190).

\subsection{Innovative activities}

These are activities that go beyond the discourses, such as inference and demonstration, criticism and evaluation, and 
imagination and creating. Teachers activities guide students to explore the theme of the text through migration and innovation, allowing students to analyze, reason and demonstrate.

Activity 7: Present grammar -- attributive clause.

Demonstrate the definition: A clause that modifies a noun or pronoun in a master-slave compound sentence.

Show the relative words on the screen:

(1) relative pronouns: that, which, who, whose, etc.

(2) relative adverbs: when, where, why, etc.

Activity 8: Guide students to analyze relative pronouns step by step, analyze these sentences, and then talk with group members to discover the function of relative pronouns separately.

(1) He is a good student who always finish his homework on time.

(2) Mark's dog is very smart and cute that can help him do many things, especially clearing the room.

(3) This is a little boy whose parents died of COVID-19.

Activity 9: Give students a minute to find and circle the relative pronouns in the text.

Activity 10: Hold a discussion in class. First, ask students what can they learn from three philosophers, then teacher also participates in the activity to express point of view.

Activity 11: Writing a short composition

You will write a short composition to your best friends to introduce a person according to the basic information in the table. Topic: Write about a famous person from ancient China according to the table (more than 120 words).

Suggested answers: Who: refers to people; whose: refers to people or something; that: refers to people or something.

Design description: It shows hidden value of the text or towards things, and allows students to evaluate the content of the text, explore the relevance of the theme to deepen the understanding of the meaning of the theme. Students can use new and old knowledge to express opinions, emotions, and attitudes, embodying correct values in the future.

\section{Conclusions}

In this paper, first and foremost, focusing on the current situation of teaching English in high school, teachers who have taught students for a rather long time are supposed to change a way of designing the reading activity from the traditional teacher-centered teaching to the learner-centered teaching, because the activity-based method in English is a further development of three-dimensional teaching goals. And for novice teachers, it is easy for them to accept new things instead of merely focusing on the students' mastery of language knowledge. Therefore, new teachers should design the reading activity with better understanding of the activity-based method in English, and cultivate students thinking quality. Finally, this paper hopes to help readers keep up with the needs of the times based on their own styles and adapt to the new development of senior high school English reading teaching.

\section{Conflicts of Interest}

The author declares no conflicts of interest regarding the publication of this paper.

\section{References}

[1] Li Y. (2004). Three Key Elements of Russian Teaching from the Perspective of Quality Education. Curriculum, Teaching Material and Method, (05): 57-61.

[2] Nuttall C. (1996). Reading Teaching Skills in a Foreign Language (New Edition). Heinemann Educational Books, London.

[3] Richards J. C. and Schmidt R. (2010). Longman Dictionary of Language Teaching and Applied Linguistics (4th edition). Routledge, London. 
[4] Scarino A. (2013). Language Assessment Literacy as Self-awareness: Understanding the Role of Interpretation in Assessment and in Teacher Learning. Language Testing, 30(3): 37.

[5] Scrivener J. (2011). Learning Teaching: The Essential Guide to English Language Teaching. Macmillan Education.

[6] Li J.W. (2019). A Study on the Application of Teaching Strategies in Senior High School English Reading Based on Bloom's Educational Objective Classification. Shenyang Normal University, Liaoning.

[7] Miao Y.N. (2011). A Comparative Study of Reading Teaching Practice for English Majors in Arts and Science Universities. Northeast Normal University, Sichuan.

[8] Ren Z. (2019). An Empirical Study of English Reading Teaching in Senior High School Based on the View of English Learning Activities. Hunan Institute of Science and Technology, Hunan.

[9] Sun G.P. (2007). Schema Theory and English Reading Teaching. Heilongjiang Researches on Higher Education, (010): 188-190.

[10] Wang Q. (2017). English Reading Teaching in the Context of Core Literacy: Problems, Principles, Goals and Approaches. English Language Learning, (02): 19-23.

[11] Ministry of Education of the People's Republic of China. (2018). General Senior High School English Curriculum Standard. People's Education Press, Beijing. 